\title{
IDENTIFIKASI RISIKO PROYEK KONSTRUKSI FLYOVER DAN UNDERPASS DI INDONESIA (KAJIAN LITERATUR)
}

\author{
Vederieq Yahya Enderzon* \\ Mahasiswa / Program Studi Magister Teknik Sipil / Jurusan Manajemen Proyek \\ Konstruksi / Universitas Katolik Parahyangan Bandung \\ *Korespondensi: vederieq.yahya@yahoo.com
}

\begin{abstract}
Flyover and underpass is one of the options to reduce congestion especially in urban areas. These flyover and underpass construction projects have unique and very complex characteristics, so they face various types of risks that may occur during the project life cycle. Risk event may occur due to several risk agents that cause it. Since the construction of flyover and underpass is very important and is a very strategic and usually large-scale project, a study of the types of risk factors that might occur during the construction of flyovers and underpass in Indonesia is needed. This research is dedicated to answering this problem. This study uses the literature review method for data collection. Based on the results of the study it was found that the risk of the conception stage is an obstacle in land acquisition, the planning stage is a change in design, the implementation stage is Occupational Health and Safety (OHS).
\end{abstract}

Keywords : flyover, identifikasi risiko, siklus proyek, underpass

\section{PENDAHULUAN}

\subsection{Latar Belakang}

Permasalahan utama berhubungan dengan pembangunan jaringan jalan khususnya di perkotaan adalah masalah kemacetan yang semakin meningkat [1]. Permasalahan kemacetan dan kendala yang dihadapi dalam pengembangan jaringan jalan di daerah perkotaan ini di antaranya adalah volume lalu lintas yang tinggi, persimpangan sebidang, keterbatasan lahan dan masalah pembebasan lahan untuk pengembangan jaringan jalan, dan perlintasan kereta api [1].

Dari permasalahan tersebut di atas, opsi penanganannya bisa menggunakan jalur transportasi tidak sebidang baik itu flyover dan underpass untuk mengurangi kemacetan terutama di area perkotaan dan mengatasi perlintasan sebidang tanpa mengganggu arus lalu lintas sebelumnya yang sudah ada [1].

Proyek konstruksi flyover dan underpass memiliki karakteristik yang khas dan sangat kompleks, sehingga menghadapi berbagai jenis risiko. Risiko yang terjadi dapat mempengaruhi biaya, waktu dan mutu dalam proyek konstruksi [2]. Kejadian risiko mungkin terjadi karena beberapa faktor risiko yang menjadi penyebabnya [3].

Mengingat pembangunan flyover dan underpass ini sangatlah penting dan biasanya berskala besar, maka diperlukan dilakukan kajian terhadap jenis-jenis risiko apa yang mungkin terjadi selama pembangunan flyover dan underpass tersebut khususnya di Indonesia pada tahap konsepsi, perencanaan, eksekusi dan operasi.

\subsection{Rumusan Masalah}

Permasalahan yang dikaji adalah faktor risiko apa saja yang mungkin terjadi pada proyek konstruksi flyover dan underpass di Indonesia?

\subsection{Tujuan Penelitian}

Tujuan penelitian ini adalah mengidentifikasi faktor risiko yang mungkin terjadi pada proyek kontruksi flyover dan underpass di Indonesia.

\subsection{Batasan Penelitian} adalah:

Batasan-batasan pada penelitian ini 
a. Identifikasi risiko proyek konstruksi flyover dan underpass yang diteliti hanya di Indonesia.

b. Identifikasi risiko proyek konstruksi flyover dan underpass yang dilakukan berdasarkan kajian literatur.

c. Pengelompokan risiko dilakukan pada tahap konsepsi, perencanaan, pelaksanaan, dan operasi proyek konstruksi flyover dan underpass di Indonesia.

d. Artikel yang dijadikan rujukan dipublikasikan dalam jurnal, skripsi/tesis, dan prosiding seminar nasional.

e. Penelusuran artikel dilakukan menggunakan mesin pencari Google Scholar dengan kata kunci dan frasa: "Identifikasi Risiko Flyover di Indonesia," "Identifikasi Risiko Underpass di Indonesia," "Proyek Konstruksi Flyover," dan "Proyek Konstruksi Underpass" dengan batasan dari tahun 2010 sampai tahun 2018.

\section{KAJIAN LITERATUR}

\subsection{Proyek Konstruksi}

Proyek didefinisikan suatu rangkaian aktivitas unik yang saling terkait untuk mencapai suatu hasil tertentu dan dilakukan dalam periode waktu tertentu pula [4]. Proyek memiliki karakteristik yang spesifik antara lain [4]:

a. Sementara (temporary).

b. Unik.

c. Progressive elaboration.

\subsection{Siklus Hidup Proyek}

Setiap proyek biasanya akan melewati tahap-tahap yang mempunyai pola tertentu yang dinamakan siklus hidup proyek [4]. Secara garis besar tahap-tahap proyek bisa dibagi menjadi [4]:

a. Tahap konsepsi

Proyek dimulai dengan ditemukannya suatu masalah, kesempatan atau kebutuhan oleh user [4].

b. Tahap perencanaan

Tahap perencanaan dalam siklus proyek akan meliputi kegiatan penyiapan rencana proyek secara detail dan penentuan spesifikasi proyek secara rinci [4].

c. Tahap eksekusi

Tahap dalam eksekusi ini meliputi desain, pengadaan, produksi dan implementasi [4].

d. Tahap operasi
Setelah hasil proyek diserahkan ke user maka proyek dianggap selesai. Keterlibatan konstraktor dianggap telah selesai lalu user mulai mengoperasikan hasil proyek tersebut [4].

Secara grafis tahap-tahap yang dilalui suatu proyek dapat digambarkan dalam Gambar 1 [4].

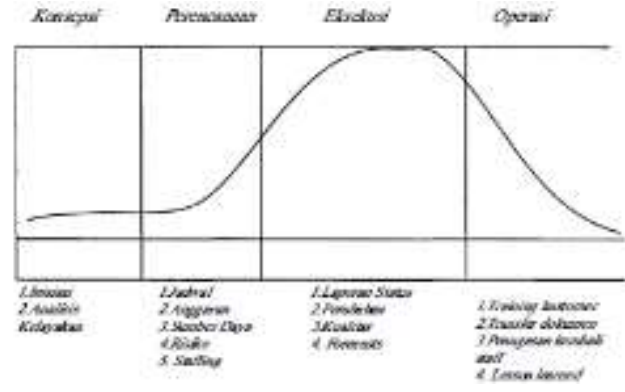

Gambar 1. Siklus Hidup Proyek Sumber : Santoso, 2009 [4]

\subsection{Risiko}

Risiko adalah ketidakpastian yang berdampak pada sasaran, dampak adalah penyimpangan (deviasi) dari sasaran yang diharapkan [5]. Dampak ini dapat timbul sebagai akibat dari suatu tindakan, atau kegagalan dari penanganan suatu peluang atau ancaman [5]. Risiko pada proyek adalah kejadian atau kondisi yang jika terjadi dapat memiliki efek positif atau negatif pada satu atau banyak tujuan proyek [2]. Menurut Pertiwi et al. (2016), risiko (risk) dapat didefinisikan sebagai peluang terjadinya kejadian yang merugikan yang diakibatkan adanya ketidakpastian (uncertainty) dari apa yang akan dihadapai [6].

\subsubsection{Manajemen Risiko}

Manajemen risiko meliputi proses melaksanakan perencanaan manajemen risiko, identifikasi, analisis, perencanaan respon risiko, dan mengontrol risiko yang ada pada proyek [2]. Tujuan manajemen risiko proyek adalah untuk meningkatkan kemungkinan kejadian di proyek yang positif dan mengurangi kemungkinan kejadian proyek yang negatif [2].

\subsubsection{Tahap Manajemen Risiko}

Dalam PMBOK Sixth Edition 2017, proses dalam manajemen risiko adalah sebagai berikut [2]:
a. Merencanakan manajemen risiko
b. Mengidentifikasi risiko
c. Melakukan analisis risiko kualitatif
d. Melakukan analisis risiko kuantitatif
e. Merencanakan respons risiko 
f. Mengontrol risiko

Dalam ISO 31000-2018, proses dalam manajemen risiko adalah [3]:

a. Komunikasi dan konsultasi

b. Lingkup, konteks dan kriteria

c. Asesmen risiko

i. Identifikasi risiko

ii. Analisis risiko

iii. Evaluasi risiko

d. Perlakuan risiko

e. Pemantauan dan kaji ulang

f. Pencatatan dan pelaporan

\section{METODOLOGI PENELITIAN}

Penelitian ini menggunakan metode kajian studi literatur. Informasi yang diperoleh adalah jenis-jenis risiko proyek konstruksi flyover dan underpass di Indonesia. Risikorisiko yang ada dikelompokkan berdasar siklus hidup proyek, meliputi tahap konsepsi, perencanaan, eksekusi dan operasi. Metodologi penelitian dalam penelitian ini seperti terlihat pada Gambar 2.

\section{HASIL DAN PEMBAHASAN}

\subsection{Analisis Bibiometrik}

Penelitian terdahulu tentang identifikasi risiko proyek konstruksi flyover dan underpass

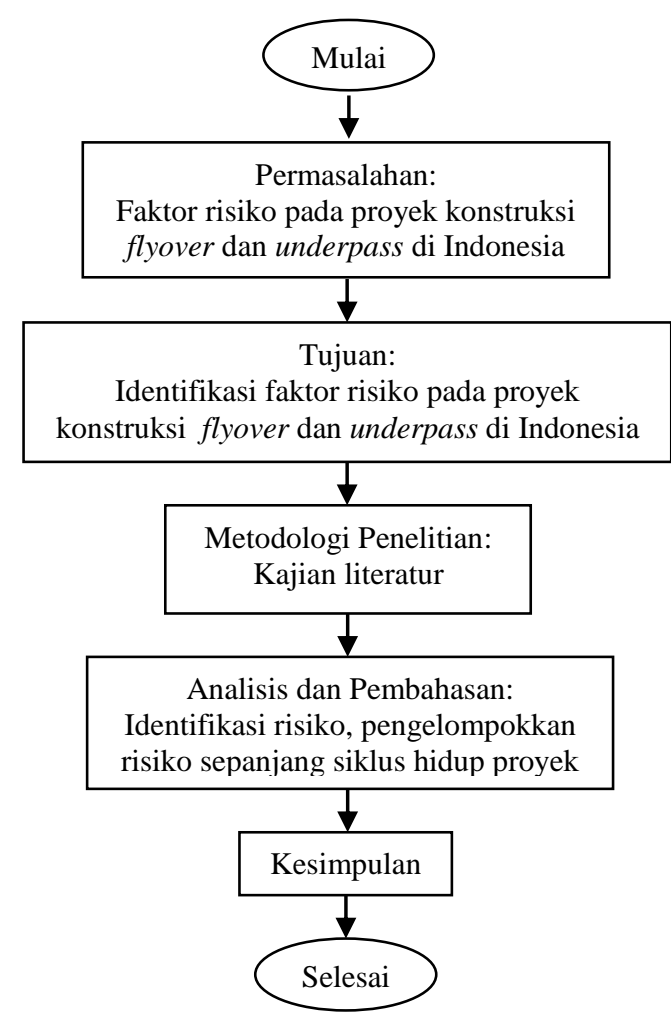

Gambar 2. Metodologi Penelitian

di Indonesia yang dianalisis pada penelitian ini berjumlah 12 literatur yang tersaji pada Tabel 1.

Tabel 1. Penelitian Terdahulu Tentang Identifikasi Risiko Pada Proyek Konstruksi Flyover dan Underpass di Indonesia

\begin{tabular}{|c|c|c|c|c|c|}
\hline No. & Judul Artikel & Nama Publikasi & Nama Penulis & $\begin{array}{l}\text { Tahun } \\
\text { Terbit }\end{array}$ & Metode dan Hasil Penelitian \\
\hline 1 & $\begin{array}{l}\text { Analisis Risiko Pada } \\
\text { Proyek Flyover Pasar } \\
\text { Kembang Surabaya }\end{array}$ & n/a (Tesis) & $\begin{array}{l}\text { Bernardus Bayu } \\
\text { Baskoro, } \\
\text { Cahyono } \\
\text { Bintang N, M } \\
\text { Arif Rohman. }\end{array}$ & 2012 & $\begin{array}{l}\text { Metode Severity Index dan } \\
\text { Matriks Probabilitas- } \\
\text { Dampak. } \\
\text { Hasil: identifikasi risiko, } \\
\text { analisis risiko dan respons } \\
\text { risiko. }\end{array}$ \\
\hline 2 & $\begin{array}{l}\text { Analisa Risiko Pada } \\
\text { Proyek Pembangunan } \\
\text { Underpass di Simpang } \\
\text { Dewa Ruci Kuta Bali. }\end{array}$ & $\begin{array}{l}\text { Jurnal Teknik } \\
\text { POMITS } \\
\text { (2013) Vol. 2, } \\
\text { No. 2, C.72- } \\
\text { C.77. }\end{array}$ & $\begin{array}{l}\text { Ayunita Indria } \\
\text { Dewi dan } \\
\text { Cahyono } \\
\text { Bintang } \\
\text { Nurcahyo. } \\
\end{array}$ & 2013 & $\begin{array}{l}\text { Metode risk register. } \\
\text { Hasil: identifikasi risiko } \\
\text { terhadap waktu dan risiko } \\
\text { terhadap biaya. }\end{array}$ \\
\hline 3 & $\begin{array}{l}\text { Identifikasi Dan Analisa } \\
\text { Risiko Kecelakaan Kerja } \\
\text { Dengan Metode FMEA } \\
\text { (Failure Mode And Effect } \\
\text { Analysis) Dan FTA } \\
\text { (Fault Tree Analysis) Di } \\
\text { Proyek Jalan Tol } \\
\text { Surabaya - Mojokerto. }\end{array}$ & $\begin{array}{l}\text { Jurnal Teknik } \\
\text { Pomits (2014) } \\
\text { Vol.1, No.1, 1-5. }\end{array}$ & $\begin{array}{l}\text { Yessi Yolanda } \\
\text { Sinaga, } \\
\text { Cahyono } \\
\text { Bintang N., dan } \\
\text { Trijoko Wahyu } \\
\text { Adi. }\end{array}$ & 2014 & $\begin{array}{l}\text { Metode FTA dan FMEA } \\
\text { Hasil: identifikasi risiko dan } \\
\text { mitigasi yang dilakukan. }\end{array}$ \\
\hline 4 & $\begin{array}{l}\text { Analisis Risiko } \\
\text { Kecelakaan Kerja Pada } \\
\text { Proyek Underpass } \\
\text { Jatingaleh Semarang } \\
\text { Dengan Metode Failure } \\
\text { Mode And Effect Analysis }\end{array}$ & $\begin{array}{l}\text { Industrail } \\
\text { Engineering } \\
\text { Online Journal } \\
\text { (2017) Vol. 6, } \\
\text { No. } 4\end{array}$ & $\begin{array}{l}\text { Novie Susanto, } \\
\text { Pramudiastuti } \\
\text { A. } \\
\text { Nursyachbani. }\end{array}$ & 2016 & $\begin{array}{l}\text { Metode FMEA. } \\
\text { Hasil: identifikasi risiko dan } \\
\text { mitigasi yang dilakukan. }\end{array}$ \\
\hline
\end{tabular}




\begin{tabular}{|c|c|c|c|c|c|}
\hline No. & Judul Artikel & Nama Publikasi & Nama Penulis & $\begin{array}{l}\text { Tahun } \\
\text { Terbit }\end{array}$ & Metode dan Hasil Penelitian \\
\hline
\end{tabular}

\begin{tabular}{|c|c|c|c|c|c|}
\hline 5 & $\begin{array}{l}\text { Analisis Risiko } \\
\text { Pembangunan Underpass } \\
\text { Dewa Ruci }\end{array}$ & $\begin{array}{l}\text { Jurnal Spektran } \\
\text { (2016) Vol.4 } \\
\text { No.1, 79-87. }\end{array}$ & $\begin{array}{l}\text { I Gede Trisna } \\
\text { Sura Nata, I G. } \\
\text { A. Adnyana } \\
\text { Putera, Gd. } \\
\text { Astawa Diputra. }\end{array}$ & 2016 & $\begin{array}{l}\text { Metode risk register. } \\
\text { Hasil: identifikasi risiko, } \\
\text { mengetahui risiko yang } \\
\text { dominan dan cara } \\
\text { mitigasinya. }\end{array}$ \\
\hline 6 & $\begin{array}{l}\text { Manajemen Risiko } \\
\text { Proyek Pembangunan } \\
\text { Underpass Gatot Subroto } \\
\text { Denpasar }\end{array}$ & $\begin{array}{l}\text { Jurnal } \\
\text { Akuntansi, } \\
\text { Ekonomi dan } \\
\text { Manajemen } \\
\text { Bisnis, (2016) } \\
\text { Vol. 4, No. 1, 1- } \\
6 . \\
\end{array}$ & $\begin{array}{l}\text { I Gusti Agung } \\
\text { Istri Mas } \\
\text { Pertiwi, Wayan } \\
\text { Sri } \\
\text { Kristinayanti, I } \\
\text { Gede Made Oka } \\
\text { Aryawan. } \\
\end{array}$ & 2016 & $\begin{array}{l}\text { Metode risk register. } \\
\text { Hasil: identifikasi risiko. }\end{array}$ \\
\hline 7 & $\begin{array}{l}\text { Analisis Finansial } \\
\text { Pembangunan Underpass } \\
\text { Gatot Subroto Denpasar } \\
\text { Dengan Simulasi Monte } \\
\text { Carlo. }\end{array}$ & $\begin{array}{l}\text { Jurnal } \\
\text { Politeknologi } \\
\text { (2017) Vol. 16, } \\
\text { No. 1, 93-100. }\end{array}$ & $\begin{array}{l}\text { I Gusti Agung } \\
\text { Istri Mas } \\
\text { Pertiwi, Wayan } \\
\text { Sri Kristinayanti } \\
\text { dan I Gede } \\
\text { Made Oka } \\
\text { Aryawan. }\end{array}$ & 2017 & $\begin{array}{l}\text { Metode simulasi monte carlo. } \\
\text { Hasil analisis terhadap } \\
\text { extreme risk dan high risk } \\
\text { yang terjadi. }\end{array}$ \\
\hline 8 & $\begin{array}{l}\text { Analisis Manajemen } \\
\text { Risiko Pada Proyek } \\
\text { Pembangunan Jalan Tol } \\
\text { (Studi Kasus Proyek } \\
\text { Pembangunan Jalan Tol } \\
\text { Solo-Ngawi-Kertosono } \\
\text { Ruas Ngawi-Kertosono } \\
\text { Paket 3) }\end{array}$ & n/a (Tesis) & $\begin{array}{l}\text { Nurcahyo Budi } \\
\text { Santoso. }\end{array}$ & 2017 & $\begin{array}{l}\text { Metode Risk Breakdown } \\
\text { Structure. } \\
\text { Hasil identifikasi risiko yang } \\
\text { terjadi. }\end{array}$ \\
\hline 9 & $\begin{array}{l}\text { Implementasi Manajemen } \\
\text { Risiko Sistem Kesehatan, } \\
\text { Keselamatan Kerja dan } \\
\text { Lingkungan (K3L) pada } \\
\text { Pembangunan Flyover } \\
\text { Pegangsaan 2 Kelapa } \\
\text { Gading Jakarta Utara } \\
\end{array}$ & $\begin{array}{l}\text { Media } \\
\text { Komunikasi } \\
\text { Teknik Sipil } \\
\text { (2017) Vol 23, } \\
\text { No. 2, 113-123. }\end{array}$ & $\begin{array}{l}\text { Arif Rahman } \\
\text { Hakim. }\end{array}$ & 2017 & $\begin{array}{l}\text { Metode matriks penilaian } \\
\text { risiko AS/NZS 4360: } 2004 \text {. } \\
\text { Hasil: Identifikasi risiko dan } \\
\text { pengelompokkan dalam jenis } \\
\text { risiko high, medium, low. }\end{array}$ \\
\hline 10 & $\begin{array}{l}\text { Analisis Manajemen } \\
\text { Risiko Kebijakan } \\
\text { Pembangunan Jembatan } \\
\text { Layang (Studi Pada Jln. } \\
\text { Zainal Abidin Pagar } \\
\text { Alam). }\end{array}$ & n/a (Skripsi) & $\begin{array}{l}\text { Asfhira } \\
\text { Novthya. }\end{array}$ & 2018 & $\begin{array}{l}\text { Metode risk register. } \\
\text { Hasil identifikasi risiko yang } \\
\text { terjadi pada pembangunan } \\
\text { flyover Mall Boemi Kedaton } \\
\text { (MBK). }\end{array}$ \\
\hline 11 & $\begin{array}{l}\text { Analisis Risiko Pada } \\
\text { Proyek Pembangunan } \\
\text { Flyover Tol Warungasem } \\
\text { Batang Dengan Kerangka } \\
\text { Project Complexity And } \\
\text { Risk Assesment dan } \\
\text { FMEA. }\end{array}$ & $\begin{array}{l}\text { Seminar } \\
\text { Nasional } \\
\text { IENACO (2018) } \\
\text { ISSN 2337- } \\
4349,314-321 .\end{array}$ & $\begin{array}{l}\text { Diana Puspita } \\
\text { Sari , Abra } \\
\text { Duhita N, } \\
\text { Anggita Maya } \\
\text { D, Ellery T, } \\
\text { Muhammad } \\
\text { Arman A. }\end{array}$ & 2018 & $\begin{array}{l}\text { Metode Project Complexity } \\
\text { And Risk Assesment dan } \\
\text { FMEA. } \\
\text { Hasil identifikasi risiko dan } \\
\text { mitigasi yang dilakukan. }\end{array}$ \\
\hline 12 & $\begin{array}{l}\text { Identifikasi Dan } \\
\text { Pengelolaan Risiko } \\
\text { Pembangunan Jembatan } \\
\text { Overpass } \text { Proyek } \\
\text { Pembangunan Jalan Tol } \\
\text { Pasuruan - Probolinggo } \\
\text { Seksi I Sta 13+616 } \\
\text { Dengan Metode Risk } \\
\text { Breakdown Matrix. }\end{array}$ & $\begin{array}{l}\text { n/a } \\
\text { (Skripsi/Proyek } \\
\text { Akhir) }\end{array}$ & Khilmi Zain. & 2018 & $\begin{array}{l}\text { Metode Risk Breakdown } \\
\text { Matrix (RBM) berdasarkan } \\
\text { Risk Breakdown Structure } \\
\text { (RBS) dan Work Breakdown } \\
\text { Structure (WBS). } \\
\text { Hasil identifikasi risiko dan } \\
\text { mitigasi yang dilakukan. }\end{array}$ \\
\hline
\end{tabular}




\subsubsection{Jumlah Artikel Berdasarkan Tahun Publikasi}

Berdasarkan Gambar 3 tren penulisan jurnal tentang identifikasi risiko proyek konstruksi flyover dan underpass di Indonesia relatif mengalami peningkatan setiap tahunnya walaupun tidak signifikan. Dari 12 artikel, 7 artikel terbit pada jurnal ilmiah $(58,33 \%), 4$ skripsi/tesis $(33,33 \%)$, dan $1(8,33 \%)$ prosiding seminar.

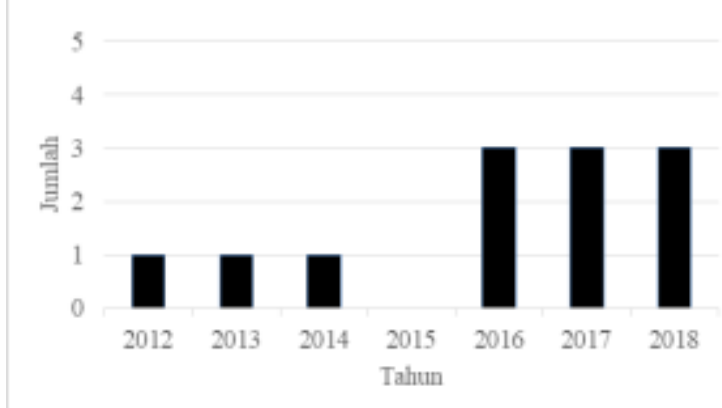

Gambar 3. Jumlah Artikel Berdasarkan Tahun Publikasi

\subsubsection{Jumlah Artikel Berdasarkan Penulis}

Penulisan artikel secara kolaboratif sebanyak 8 artikel, dan 4 artikel ditulis secara individu. Artinya penelitian tentang identifikasi risiko pada proyek konstruksi flyover dan underpass di Indonesia lebih banyak dilakukan secara kolaboratif agar mendapatkan hasil yang lebih baik dan akurat.

\subsubsection{Jumlah Artikel Berdasarkan Jenis Analisis Risiko dan Metode yang Digunakan \\ Dari 12 artikel yang ditinjau, 11 artikel} diteliti dengan analisis risiko secara kualitatif sedangkan sisanya 1 artikel diteliti dengan analisis kuantitatif. Hal ini dapat dipahami mengingat analisis secara kualitatif lebih sederhana, mudah dikerjakan dan membutuhkan biaya yang relatif murah.

Dari 11 artikel diteliti dengan analisis risiko secara kualitatif, $8 \mathrm{di}$ antaranya menggunakan metode Risk Register sedangkan sedangkan sisanya 3 artikel menggunakan metode FMEA. Dan 1 artikel yang menggunakan analisis kuantitatif memanfaatkan metode Simulasi Monte Carlo.

\subsection{Identifikasi Risiko Pada Siklus Proyek \\ Pengelompokan identifikasi risiko} sepanjang siklus hidup proyek yang mungkin terjadi pada konstruksi flyover dan underpass dan dampak terhadap biaya, waktu dan mutu disajikan pada Tabel 2.

Tabel 2. Identifikasi Risiko Pada Proyek Konstruksi Flyover dan Underpass dan Dampak Terhadap Biaya, Waktu dan Mutu

\begin{tabular}{|c|c|c|c|c|c|c|}
\hline \multirow{2}{*}{$\begin{array}{l}\text { Siklus } \\
\text { Proyek }\end{array}$} & \multirow{2}{*}{ Risiko } & \multicolumn{2}{|c|}{ Risiko Pada Konstruksi } & \multicolumn{3}{|c|}{ Dampak Terhadap } \\
\hline & & Flyover & Underpass & Biaya & Mutu & Waktu \\
\hline \multirow{5}{*}{$\begin{array}{c}\text { Tahap } \\
\text { Konsepsi }\end{array}$} & Kurangnya komunikasi/koordinasi & $\sqrt{ }$ & $\sqrt{ }$ & - & - & $\sqrt{ }$ \\
\hline & Demo, ketikpuasan masyarakat & $\sqrt{ }$ & $\sqrt{ }$ & - & - & $\sqrt{ }$ \\
\hline & Kendala dalam pembebasan lahan & $\sqrt{ }$ & $\sqrt{ }$ & $\sqrt{ }$ & - & $\sqrt{ }$ \\
\hline & Perselisihan antar-elite & $\sqrt{ }$ & $\sqrt{ }$ & - & - & $\sqrt{ }$ \\
\hline & $\begin{array}{l}\text { Berita media cetak dan elektronik yang } \\
\text { negatif }\end{array}$ & $\sqrt{ }$ & $\sqrt{ }$ & - & - & $\sqrt{ }$ \\
\hline \multirow{7}{*}{$\begin{array}{c}\text { Tahap } \\
\text { Perencanaan }\end{array}$} & Perubahan desain & $\sqrt{ }$ & $\sqrt{ }$ & $\sqrt{ }$ & - & $\sqrt{ }$ \\
\hline & Pengalaman manajemen yang kurang & $\sqrt{ }$ & $\sqrt{ }$ & $\sqrt{ }$ & $\sqrt{ }$ & $\sqrt{ }$ \\
\hline & Kesalahan estimasi waktu & $\sqrt{ }$ & $\sqrt{ }$ & - & - & $\sqrt{ }$ \\
\hline & Kesalahan estimasi biaya & $\sqrt{ }$ & $\sqrt{ }$ & $\sqrt{ }$ & - & \\
\hline & $\begin{array}{l}\text { Dokumen kontrak yang tidak sesuai/tidak } \\
\text { lengkap }\end{array}$ & $\sqrt{ }$ & $\sqrt{ }$ & - & - & $\sqrt{ }$ \\
\hline & Proyek tidak lolos uji kelayakan & $\sqrt{ }$ & $\sqrt{ }$ & - & $\sqrt{ }$ & $\sqrt{ }$ \\
\hline & Data perencanaan yang kurang akurat & $\sqrt{ }$ & $\sqrt{ }$ & $\sqrt{ }$ & $\sqrt{ }$ & $\sqrt{ }$ \\
\hline \multirow[t]{5}{*}{$\begin{array}{c}\text { Tahap } \\
\text { Pelaksanaan }\end{array}$} & Keamanan dan keselamatan kerja (K3) & $\sqrt{ }$ & $\sqrt{ }$ & $\sqrt{ }$ & $\sqrt{ }$ & $\sqrt{ }$ \\
\hline & Pengawasan proyek tidak baik & $\sqrt{ }$ & $\sqrt{ }$ & $\sqrt{ }$ & $\sqrt{ }$ & $\sqrt{ }$ \\
\hline & $\begin{array}{l}\text { Material kurang berkualitas/tidak sesuai } \\
\text { spesifikasi }\end{array}$ & $\sqrt{ }$ & $\sqrt{ }$ & - & $\sqrt{ }$ & - \\
\hline & Muka air dangkal & - & $\sqrt{ }$ & $\sqrt{ }$ & $\sqrt{ }$ & $\sqrt{ }$ \\
\hline & Mutu pekerjaan tidak tercapai & $\sqrt{ }$ & $\sqrt{ }$ & - & $\sqrt{ }$ & - \\
\hline
\end{tabular}




\begin{tabular}{|c|c|c|c|c|c|c|}
\hline \multirow{11}{*}{$\begin{array}{l}\text { Siklus } \\
\text { Proyek }\end{array}$} & \multirow{2}{*}{ Risiko } & \multicolumn{2}{|c|}{ Risiko Pada Konstruksi } & \multicolumn{3}{|c|}{ Dampak Terhadap } \\
\hline & & Flyover & Underpass & Biaya & Mutu & Waktu \\
\hline & Peralatan yang kurang memadai & $\sqrt{ }$ & $\sqrt{ }$ & $\sqrt{ }$ & $\sqrt{ }$ & $\sqrt{ }$ \\
\hline & $\begin{array}{l}\text { Kenaikan suku bunga, inflasi, kenaikan } \\
\text { harga material dan upah tenaga kerja }\end{array}$ & $\sqrt{ }$ & $\sqrt{ }$ & $\sqrt{ }$ & - & $\sqrt{ }$ \\
\hline & Bencana alam, pencemaran lingkungan & $\sqrt{ }$ & $\sqrt{ }$ & $\sqrt{ }$ & $\sqrt{ }$ & $\sqrt{ }$ \\
\hline & $\begin{array}{l}\text { Kontraktor atau subkontraktor kurang } \\
\text { berkompeten }\end{array}$ & $\sqrt{ }$ & $\sqrt{ }$ & $\sqrt{ }$ & $\sqrt{ }$ & $\sqrt{ }$ \\
\hline & Dokumentasi dan pelaporan yang tidak baik & $\sqrt{ }$ & $\sqrt{ }$ & - & - & $\sqrt{ }$ \\
\hline & Keterlambatan proyek & $\sqrt{ }$ & $\sqrt{ }$ & $\sqrt{ }$ & $\sqrt{ }$ & $\sqrt{ }$ \\
\hline & $\begin{array}{l}\text { Adanya utilitas yang mengganggu } \\
\text { pelaksanaan proyek }\end{array}$ & $\sqrt{ }$ & $\sqrt{ }$ & $\sqrt{ }$ & - & $\sqrt{ }$ \\
\hline & Metode pelaksanaan tidak sesuai & $\sqrt{ }$ & $\sqrt{ }$ & $\sqrt{ }$ & $\sqrt{ }$ & $\sqrt{ }$ \\
\hline & Produktivitas tenaga kerja kurang baik & $\sqrt{ }$ & $\sqrt{ }$ & $\sqrt{ }$ & - & $\sqrt{ }$ \\
\hline $\begin{array}{c}\text { Tahap } \\
\text { Operasi }\end{array}$ & - & - & - & - & - & - \\
\hline \multicolumn{2}{|r|}{ Jumlah } & 25 & 26 & 16 & 13 & 23 \\
\hline
\end{tabular}

Dari Tabel 2 terlihat semua risiko konstruksi flyover juga terjadi pada konstruksi underpass. Ada satu risiko yang khas pada konstruksi underpass yang tidak ada pada konstruksi flyover yaitu muka air dangkal. Muka air yang dangkal pada proyek konstruksi underpass cukup memberikan kesulitan saat proses penggalian tanah untuk konstruksi underpass.
Pada Tabel 3 dapat dilihat pengelompokan identifikasi risiko yang mungkin terjadi. Parameter dalam artikel yang dikaji yang memiliki persamaan akan dijadikan dalam satu parameter jenis risiko. Parameter keselamatan dan kesehatan kerja (K3) merupakan parameter jenis risiko yang paling memiliki persamaan dan sering terjadi yaitu terdapat dalam 10 dari 12 artikel.

Tabel 3. Identifikasi Risiko Pada Sklus Proyek Konstruksi Flyover dan Underpass di Indonesia

\begin{tabular}{|c|c|c|c|c|c|c|c|c|c|c|c|c|c|}
\hline \multirow{2}{*}{ Siklus Proyek } & \multirow{2}{*}{ Jenis Risiko } & \multicolumn{12}{|c|}{ Referensi } \\
\hline & & $\mathrm{R} 1$ & $\mathrm{R} 2$ & R3 & $\mathrm{R} 4$ & $\mathrm{R} 5$ & R6 & R7 & $\mathrm{R} 8$ & R9 & R10 & R11 & R12 \\
\hline \multirow[t]{5}{*}{$\begin{array}{c}\text { Tahap } \\
\text { Konsepsi }\end{array}$} & $\begin{array}{l}\text { Kurangnya } \\
\text { komunikasi/koordinasi }\end{array}$ & $\sqrt{ }$ & - & - & - & - & - & $\sqrt{ }$ & - & - & - & - & - \\
\hline & $\begin{array}{l}\text { Demo, ketikpuasan } \\
\text { masyarakat. }\end{array}$ & $\sqrt{ }$ & - & - & - & - & - & - & - & - & - & - & - \\
\hline & $\begin{array}{l}\text { Kendala dalam } \\
\text { pembebasan lahan. }\end{array}$ & - & $\sqrt{ }$ & - & $\sqrt{ }$ & - & $\sqrt{ }$ & - & - & - & - & - & - \\
\hline & Perselisihan antar-elite. & - & - & $\sqrt{ }$ & - & - & - & - & - & - & - & - & - \\
\hline & $\begin{array}{l}\text { Berita media cetak dan } \\
\text { elektronik yang negatif. }\end{array}$ & - & - & - & - & - & - & $\sqrt{ }$ & - & - & - & - & - \\
\hline \multirow{7}{*}{$\begin{array}{c}\text { Tahap } \\
\text { Perencanaan }\end{array}$} & Perubahan desain. & $\sqrt{ }$ & $\sqrt{ }$ & $\sqrt{ }$ & $\sqrt{ }$ & - & $\sqrt{ }$ & $\sqrt{ }$ & - & - & - & - & - \\
\hline & $\begin{array}{l}\text { Pengalaman manajemen } \\
\text { yang kurang. }\end{array}$ & $\sqrt{ }$ & - & - & - & - & - & - & - & - & - & - & - \\
\hline & $\begin{array}{l}\text { Kesalahan estimasi } \\
\text { waktu. }\end{array}$ & $\sqrt{ }$ & - & - & - & - & - & - & - & - & - & - & - \\
\hline & Kesalahan estimasi biaya. & $\sqrt{ }$ & $\sqrt{ }$ & - & - & - & $\sqrt{ }$ & - & - & - & - & - & - \\
\hline & $\begin{array}{l}\text { Dokumen kontrak yang } \\
\text { tidak sesuai/tidak } \\
\text { lengkap. }\end{array}$ & $\sqrt{ }$ & - & - & - & - & $\sqrt{ }$ & - & - & - & - & - & - \\
\hline & $\begin{array}{l}\text { Proyek tidak lolos uji } \\
\text { kelayakan. }\end{array}$ & - & - & - & - & - & $\sqrt{ }$ & - & - & - & - & - & - \\
\hline & $\begin{array}{l}\text { Data perencanaan yang } \\
\text { kurang akurat } \\
\text { /perencanaan salah. }\end{array}$ & - & - & - & $\sqrt{ }$ & - & $\sqrt{ }$ & - & - & - & $\sqrt{ }$ & - & - \\
\hline \multirow[t]{2}{*}{$\begin{array}{c}\text { Tahap } \\
\text { Pelaksanaan }\end{array}$} & $\begin{array}{l}\text { Keamanan dan } \\
\text { keselamatan kerja (K3). }\end{array}$ & $\sqrt{ }$ & $\sqrt{ }$ & - & $\sqrt{ }$ & $\sqrt{ }$ & $\sqrt{ }$ & $\sqrt{ }$ & $\sqrt{ }$ & $\sqrt{ }$ & $\sqrt{ }$ & $\sqrt{ }$ & - \\
\hline & $\begin{array}{l}\text { Pengawasan proyek tidak } \\
\text { baik. }\end{array}$ & $\sqrt{ }$ & $\sqrt{ }$ & - & - & - & - & $\sqrt{ }$ & - & - & - & - & - \\
\hline
\end{tabular}




\begin{tabular}{|c|c|c|c|c|c|c|c|c|c|c|c|c|c|}
\hline \multirow{14}{*}{ Siklus Proyek } & \multirow{2}{*}{ Jenis Risiko } & \multicolumn{12}{|c|}{ Referensi } \\
\hline & & $\mathrm{R} 1$ & $\mathrm{R} 2$ & R3 & $\mathrm{R} 4$ & R5 & R6 & R7 & R8 & R9 & R10 & R11 & R12 \\
\hline & $\begin{array}{l}\text { Material kurang } \\
\text { berkualitas/tidak sesuai } \\
\text { spesifikasi. }\end{array}$ & $\sqrt{ }$ & $\sqrt{ }$ & - & $\sqrt{ }$ & - & - & - & - & $\sqrt{ }$ & - & - & $\sqrt{ }$ \\
\hline & Muka air dangkal. & - & - & - & - & - & - & $\sqrt{ }$ & - & - & $\sqrt{ }$ & - & - \\
\hline & $\begin{array}{l}\text { Mutu pekerjaan tidak } \\
\text { tercapai. }\end{array}$ & $\sqrt{ }$ & - & - & - & - & - & - & - & - & - & - & - \\
\hline & $\begin{array}{l}\text { Peralatan yang kurang } \\
\text { memadai. }\end{array}$ & $\sqrt{ }$ & - & - & $\sqrt{ }$ & - & - & - & - & - & - & - & $\sqrt{ }$ \\
\hline & $\begin{array}{l}\text { Kenaikan suku bunga, } \\
\text { inflasi, kenaikan harga } \\
\text { material dan upah tenaga } \\
\text { kerja. }\end{array}$ & $\sqrt{ }$ & $\sqrt{ }$ & $\sqrt{ }$ & - & - & - & - & - & - & - & - & - \\
\hline & $\begin{array}{l}\text { Bencana alam, kondisi } \\
\text { lapangan, cuaca, dan } \\
\text { pencemaran lingkungan. }\end{array}$ & $\sqrt{ }$ & $\sqrt{ }$ & - & - & $\sqrt{ }$ & $\sqrt{ }$ & - & $\sqrt{ }$ & $\sqrt{ }$ & - & $\sqrt{ }$ & $\sqrt{ }$ \\
\hline & $\begin{array}{l}\text { Kontraktor atau } \\
\text { subkontraktor yang } \\
\text { kurang berkompeten. }\end{array}$ & $\sqrt{ }$ & $\sqrt{ }$ & - & $\sqrt{ }$ & - & $\sqrt{ }$ & - & - & - & - & - & - \\
\hline & $\begin{array}{l}\text { Dokumentasi dan } \\
\text { pelaporan yang tidak } \\
\text { baik. }\end{array}$ & $\sqrt{ }$ & - & - & - & - & - & - & - & - & - & - & - \\
\hline & Keterlambatan proyek. & - & $\sqrt{ }$ & $\sqrt{ }$ & $\sqrt{ }$ & - & $\sqrt{ }$ & $\sqrt{ }$ & - & - & - & - & - \\
\hline & $\begin{array}{l}\text { Adanya utilitas yang } \\
\text { mengganggu pelaksanaan } \\
\text { proyek. }\end{array}$ & - & - & - & - & - & $\sqrt{ }$ & $\sqrt{ }$ & - & - & - & - & - \\
\hline & $\begin{array}{l}\text { Metode pelaksanaan tidak } \\
\text { sesuai. }\end{array}$ & - & - & - & - & - & $\sqrt{ }$ & $\sqrt{ }$ & - & - & - & - & $\sqrt{ }$ \\
\hline & $\begin{array}{l}\text { Produktivitas tenaga kerja } \\
\text { kurang baik. }\end{array}$ & - & - & - & - & - & - & $\sqrt{ }$ & - & - & - & - & - \\
\hline $\begin{array}{c}\text { Tahap } \\
\text { Operasi }\end{array}$ & - & - & - & - & - & - & - & - & - & - & - & - & - \\
\hline & Jumlah & 16 & 10 & 4 & 8 & 2 & 12 & 10 & 2 & 3 & 3 & 2 & 4 \\
\hline
\end{tabular}

Catatan : R1 = Dewi dan Nurcahyo,2013 [7]; R2 = Pertiwi et al.,2017 [8]; R3 = Novthya,2018 [9];

R4 = Santoso,2017 [10]; R5 = Susanto dan Nursyachbai,2016 [11]; R6 = Sari et al.,2018 [12]; R7 = Nata et al.,2016 [13]; R8 = Zain,2018 [14]; R9 = Sinaga et al.,2014 [15]; R10 = Pertiwi et al.,2016 [6]; R11 = Hakim,2017 [16]; R12 = Baskoro et al.,2012 [17].

Dari Tabel 3 dapat dilihat bahwa risiko paling banyak terjadi pada tahap pelaksanaan dengan risiko keamanan dan keselamatan kerja yang paling sering terjadi.

Risiko tertinggi selanjutnya adalah risiko pada tahap perencanaan. Berdasarkan Tabel 3, risiko dalam tahap perencanaan yang sering terjadi adalah adanya perubahan desain.

Risiko tertinggi ketiga adalah risiko pada tahap konsepsi. Berdasarkan Tabel 3 risiko dalam tahap konsepsi yang sering terjadi adalah kendala dalam pembebasan lahan.

Berdasarkan Tabel 3 yang telah diteliti tidak ada satupun risiko yang ditemukan dalam tahap operasi.

\section{KESIMPULAN}

Kesimpulan terkait risiko pada proyek konstruksi flyover dan underpass di Indonesia, yaitu sebagai berikut:

a. Pada tahap konsepsi teridentifikasi risikorisiko, e.g., kurangnya komunikasi/ koordinasi, demo ketikpuasan masyarakat, kendala dalam pembebasan lahan, perselisihan antar-elite dan berita media cetak dan elektronik yang negatif.

b. Pada tahap perencanaan teridentifikasi risiko-risiko, e.g., adanya perubahan desain, pengalaman manajemen yang kurang, kesalahan estimasi waktu, kesalahan estimasi biaya, dokumen kontrak yang tidak sesuai/tidak lengkap, proyek tidak lolos uji kelayakan dan data perencanaan yang kurang akurat/perencanaan salah.

c. Pada tahap pelaksanaan teridentifikasi risiko-risiko, e.g., keamanan dan 
keselamatan kerja (K3), pengawasan proyek tidak baik, material kurang berkualitas/tidak sesuai spesifikasi, muka air dangkal, mutu pekerjaan tidak tercapai, peralatan yang kurang memadai, kenaikan suku bunga, inflasi, kenaikan harga material dan upah tenaga kerja, bencana alam, kondisi lapangan, faktor cuaca dan pencemaran lingkungan, dokumentasi dan pelaporan yang tidak baik, keterlambatan proyek, adanya utilitas yang mengganggu pelaksanaan proyek, metode pelaksanaan tidak sesuai, kontraktor atau subkontraktor yang kurang berkompeten dan produktivitas tenaga kerja kurang baik.

d. Pada tahap operasi tidak teridentifikasi adanya risiko yang terjadi.

\section{DAFTAR PUSTAKA}

[1] Aldiamar, F., Ariestianty, S. K., Putra, H., Numan, A., Nugraha, W., Hanafiah, D. M., Tanan, N., Purnama, A. S., Sumardi, T. S., Naskah Ilmiah Kajian Perencanaan Struktur Baja Bergelombang Lintas Atas Dan Penanganan Longsoran Lereng Jalan, Bandung, 2015.

[2] PMBOK - Sixth Edition, A Guide to The Project Management Body of Knowledge, Project Management Institute, 2017.

[3] ISO 31000-2018 Risk Management Guidelines. International Organization for Standardization, 2018.

[4] Santoso, B., Manajemen Proyek Konsep \& Implementasi, Yogyakarta, 2009.

[5] Susilo, L. J., \& Kaho, V. R., Manajemen Risiko Berbasis ISO 31000:2018, Jakarta, 2018.

[6] Pertiwi, I. G. A. I. M., Kristinayanti, W. S., \& Aryawan, I. G. M. A., Manajemen Risiko Proyek Pembangunan Underpass Gatoto Subroto Denpasar, Jurnal Akuntansi, Ekonomi Dan Manajemen Bisnis Vol. 4, No. 1, 2016:16.

[7] Dewi, A. I., \& Nurcahyo, C. B., Analisa Risiko Pada Proyek Pembangunan Underpass Di Simpang Dewi Ruci Kuta Bali. Jurnal Teknik Pomits Vol. 2, No. 2, 2013:C.72-C.77.

[8] Pertiwi, I. G. A. I. M.,, Kristinayanti, W. S., \& Aryawan, I. G. M. O., Analisis Finansial Pembanguan Underpass Gatot Subroto Denpasar Dengan Simulasi Monte Carlo.
Jurnal Politeknologi Vol. 16 No. 1, 2017:93100.

[9] Novthya, A, Analisis Manajemen Risiko Kebijakan Pembangunan Jembatan Layang (Studi Pada Jln. Zainal Abidin Pagar Alam), Skripsi, Universitas Lampung, 2018.

[10] Santoso, N. B., Analisis Manajemen Risiko Pada Proyek Pembangunan Jalan Tol (Studi Kasus Proyek Pembangunan Jalan Tol SoloNgawi-Kertosono Ruas Ngawi-Kertosono Paket 3), Tesis, Universitas Muhammadiyah Surakarta, 2017.

[11] Susanto, N., \& Nursyachbani, P. A., Analisis Risiko Kecelakaan Kerja Pada Proyek Underpass Jatingaleh Semarang Dengan Metode Failure Mode And Effect Analysis (FMEA), Industrail Engineering Online Journal 2017, Vol. 6, No. 4.

[12] Sari, D. P., Duhita, A., Maya, A., Ellery, T., \& Arman, M., Analisis Risiko Pada Proyek Pembangunan Flyover Tol Warungasem Batang Dengan Kerangka Project Complexity And Risk Assesment Dan FMEA, Prosiding Seminar Nasional IENOCO-2018, 2018:314321.

[13] Nata, I. G. T. S., Putera, I. G. A., \& Diputra, G. A., Analisis Risiko Pembangunan Underpass Dewa Ruci. Jurnal Spektran Vol. 4, No. 1, 2016:79-87.

[14] Zain, K., Identifikasi Dan Pengelolaan Risiko Pembangunan Jembatan Overpass Proyek Pembangunan Jalan Tol Pasuruan-Probolinggo Seksi I Sta. 13+616 Dengan Metode Risk Breakdown Matrix, Skipsi, Universitas Gadjah Mada, 2018

[15] Sinaga, Y. Y., \& Bintang, C. N., \& Adi, T. W., Identifikasi Dan Analisa Risiko Kecelakaan Kerja Dengan Metode FMEA (Failure Mode And Effect Analysis) Dan FTA (Fault Tree Analysis) Di Proyek Jalan Tol SurabayaMojokerto. Jurnal Teknik Pomits Vol. 1, No. 1, 2014:1-5.

[16] Hakim, A. R., Implementasi Manajemen Risiko Sistem Kesehatan, Keselamatan Kerja Dan Lingkungan (K3L) Pada Pembangunan Flyover Pegangsaan 2 Kelapa Gading Jakarta Utara. Media Komunikasi Teknik Sipil, Vol. 23, No. 2, 2017:113-123.

[17] Baskoro, B. B., Bintang, C. N., \& Rohman, M. A., Analisis Risiko Pada Proyek Flyover Pasar Kembang Surabaya, Tesis, Institut Teknologi Sepuluh November, 2012. 